\title{
DIURNAL RAINFALL ON TROPICAL CYCLONE CEMPAKA AND DAHLIA AS OBSERVED BY TRMM
}

\section{PENGAMATAN CURAH HUJAN HARIAN PADA SIKLON TROPIS CEMPAKA DAN DAHLIA OLEH DATA TRMM}

\author{
Reza Bayu Perdana ${ }^{1^{*}}$, Mutiara Halida ${ }^{2}$, Setyo Aji Pramono ${ }^{3}$ \\ ${ }^{1,3}$ Pusat Database BMKG \\ ${ }^{2}$ Stasiun Klimatologi Tangerang Selatan \\ *Email: reza.perdana@bmkg.go.id \\ Naskah masuk: 20 Desember 2019, Naskah diperbaiki: 25 Juni 2020, Naskah diterima: 27 Juli 2020
}

\section{ABSTRACT}

Two tropical cyclones (TC) were observed at the southern part of Indonesia's ocean at the end 2017, and were the first and second cyclones that were under Indonesia Tropical Cyclone Warning Centre's (TCWC) responsibility after TC Bakung in 2010. TC Cempaka formed in the southern part of Central Java Province's ocean and caused high rainfall over the south part of Java island while TC Dahlia formed in the southern part of Banten Province's ocean with lesser impact to rainfall due to its further distance from Java island than TC Cempaka storms. This research aims to understand and to compare both diurnal cycles of precipitation in the ocean where the two TCs occurred and in the land area that were impacted by the TCs. Data used in this research are three hourly averaged rainfall data from Tropical Rainfall Measurement Mission (TRMM) and Automatic Rain Gauge (ARG). Data from TRMM, especially the 3B42RT are used to determine the diurnal rainfall of precipitation in the ocean, while data from ARG are used to determine the diurnal rainfall of precipitation in the land area. The method used in this research is time series analysis of rainfall intensity during the active phase of TCs from the phase of tropical disturbance to extinction phase. The result reveal that the rainfall intensity in the ocean where the TC occurred reaches peak at night and early morning, then weaken in the morning until afternoon. Different cycles are found on land area with rainfall intensity reaches peak during the day and night and weaken in the afternoon and early morning. Keywords: storm, rainfall, cycle

\section{ABSTRAK}

Dua siklon tropis teramati di perairan bagian selatan Indonesia pada akhir 2017, menjadi siklon tropis pertama dan kedua yang terjadi di wilayah tanggung jawab Indonesia setelah siklon tropis Bakung pada 2010. Siklon tropis Cempaka terbentuk di perairan sebelah selatan Provinsi Jawa Tengah dan menyebabkan curah hujan tinggi di wilayah selatan pulau Jawa. Siklon tropis Dahlia terbentuk di sebelah selatan Provinsi Banten dengan pengaruh yang lebih kecil terhadap curah hujan di daratan disebabkan jarak yang lebih jauh. Tujuan dari penelitian ini adalah untuk mengetahui siklus harian curah hujan yang terjadi pada kedua siklon tropis tersebut, serta siklus harian yang terjadi pada wilayah terdampak saat terjadi siklon tropis. Data yang digunakan pada penelitian ini adalah curah hujan rata-rata per tiga jam dari Tropical Rainfall Measurement Mission (TRMM), khususnya data 3B42RT. Metode yang digunakan pada penelitian ini adalah analisis time series. Hasil dari penelitian ini menunjukkan bahwa ketika terjadi siklon tropis, curah hujan mencapai puncak pada malam sampai dini hari, kemudian melemah pada pagi sampai sore hari. Pada daerah terdampak di daratan, puncak hujan terjadi pada siang dan malam hari, dan melemah pada sore dan dini hari.

Kata kunci: badai, curah hujan, siklus 


\section{Introduction}

At the last of 2017, there were two tropical cyclones that appear in the southern ocean of Indonesia, precisely in the southern part of Java. The cyclones are TC Cempaka on November 27-30 and TC Dahlia from November 28 to December 2. These two cyclones are the first in the waters of southern Indonesia, as well as the third and fourth since Anggrek in 2008 and Bakung in 2010.

TC Cempaka appeared in southern Java on November 27, 2017, tend to move eastward and extinct on 30 November 2017. Based on maximum wind speed in the storm area, TC Cempaka was categorized as tropical depressions. The highest observed wind speed was 35 knots while the lowest recorded pressure was $998 \mathrm{mb}$. This category belongs to the lowest category of tropical cyclones. Although it was categorized as the weakest category for tropical cyclone, TC Cempaka gave a great impact to the land area in the south of Java island. This is due to the location of TC Cempaka which is closer to Java than any other tropical cyclone in Indonesian waters.

TC Dahlia appeared on 29 November 2017 in the western part of the island of Sumatra or southern part of Banten Province and moved to the southeast and began extinction on December 2, 2017. The maximum wind speed and pressure at the center of Dahlia storm categorized as tropical storm. The highest observed wind speed was 35 knots while the lowest recorded pressure was $998 \mathrm{mb}$. Whereas it was categorized higher than the Cempaka storm, the impact caused by Dahlia storms is smaller, due to the stormy location of Dahlia from the mainland. The track of TC Cempaka and TC Dahlia stored in the fig 1 and fig 2 as follows.

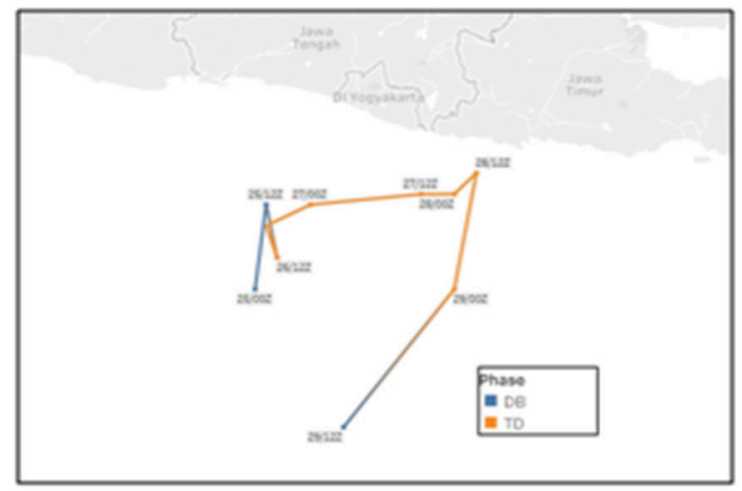

Figure 1. Track of Tropical Cyclone Cempaka

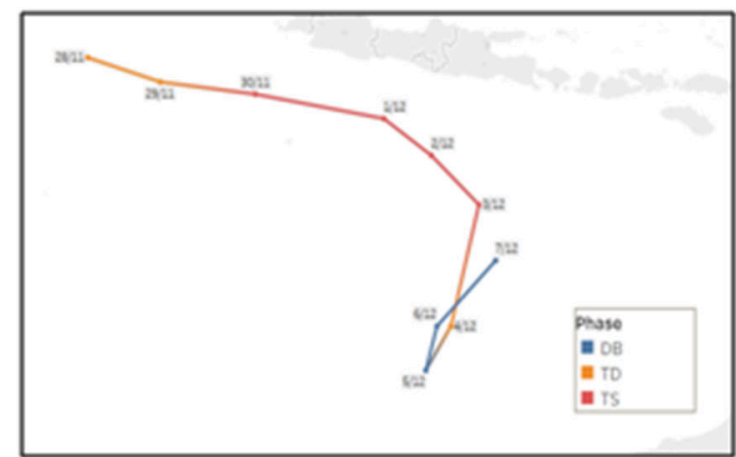

Figure 2. Track of Tropical Cyclone Dahlia

One of the weather conditions caused by tropical storms is precipitation, in the case of Cempaka and Dahlia storms that form in the tropics, it forms as rainfall. The purpose of the authors in this study is to observe the diurnal rainfall of rainfall that occurs in Cempaka and Dahlia storms.

Research on the diurnal cycle of rainfall in previous tropical storm conditions has been done by several studies, including Bowman, et $\mathrm{al}^{[1]}$, Wu${ }^{[7]}$ and Leppert and Cecil[5]. Bowman ${ }^{[1]}$ studied the tropical cyclone diurnal cycle in the Pacific Ocean climatologically using TRMM data. The result of this research is the recognition of rainfall patterns that reach the peak at night until early morning in the ocean area, and rainfall patterns that peak in the afternoon on the mainland. Wu et al (2014) examined rainfall patterns on the inner and outer circles of tropical cyclones using satellite data for a 15-year period, while Leppert and Cecil[5] used TRMM and radar data to examine diurnal cycles in tropical cyclone more detail, conclude that the peak of rain intensity occurred in the early morning.

\section{Methods}

Data used in this research are three-hourly averaged rainfall intensity data from Tropical Rainfall Measuring Mission (TRMM), especially from 3B42RT data. TRMM data has a spatial resolution of $0.25 \times 0.25$ degrees with map coverage reaching 50 degrees north latitude as well as southern latitude. The data taken are 3hour series data during the storm (since grew to extinction).Data taken in the span of November 26, 2017 at 22:30 UTC to December 7, 2017 at $22: 30$ UTC. It is a time series data that already represents 2 cyclone phenomena where cempaka cyclone occurred on 27-30 November 2017, and dahlia cyclone occurred on 29 November 2017 - 2 December 2017. Retrieval of initial and final data was longer than the date of the phenomenon of cyclone events in order 
to compare the cycle differences on prior, onset, and after cyclones.

Location data taken on the TRMM website was focused within -19.875 Sto $-0.125 \mathrm{~S}$ and 90.125 $\mathrm{E}$ to $119.875 \mathrm{E}$. This area included two cyclone phenomena.

The locations of the storm coordinate were taken from NASA where the web shows the movement of storms every 6 hours complete with storm coordinates location data.

This research uses the method of diurnal analysis of average rainfall intensity per hour obtained from TRMM 3B42RT data. This study does not distinguish between inner and outer circumference of storms due to storm diameters ranging from 100-150 km. Data series then plotted based on time stamp.

Subsidiary data used in this paper is rainfall intensity data from Geophysic Station of Yogyakarta.Diurnal rainfall analysis was performed for this location as a comparison of cyclone's, especially Cempaka. This location was chosen because it was the closest station to the Cempaka cyclone which records hourly rainfall.

\section{Results and Discussion}

Results of plot series TRMM rainfall intensity data for Cempaka and Dahlia storms were stored at fig 3 and fig 4 as follows. Red lines indicate the pre and post phase of the storm, while blue lines show the storm onset.

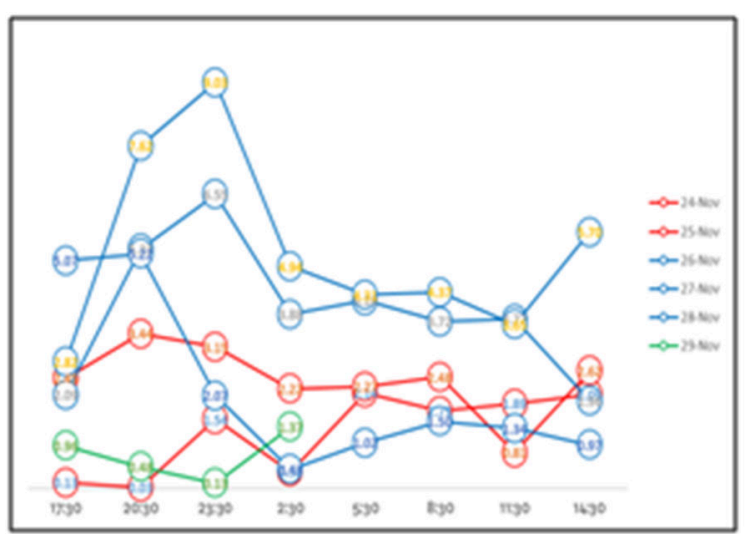

Figure 3. Three-hourly averaged rainfall intensity of TC Cempaka $(\mathrm{mm} / \mathrm{hr})$

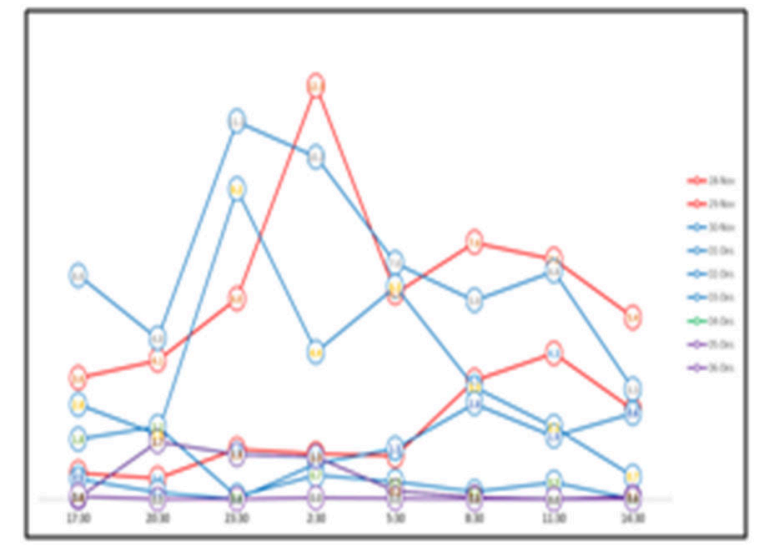

Figure 4. Three-hourly averaged rainfall intensity of TC Dahlia $(\mathrm{mm} / \mathrm{hr})$

Graphs show clear diurnal variations in Cempaka storms, with peaks of rain intensity occurring at night and early morning, then storms subside in the morning until noon. Where as in Dahlia storms there is variability in diurnal variations that change when the storm changes phase. At the time of the tropical depression phase, the peak rain intensity occurs during the day and decays at night until the early hours of the morning. This condition changes when the Dahlia storm enter the tropical cyclone phase, which is marked by the pressure drop at the center of the storm and the rising wind speed in the storm area. At the time of the tropical cyclone phase, an increase in rainfall intensity reaches $300 \%$ compared to the phase of tropical depression, and the intensity of rain reaches its peak at night until early morning and decays in the morning until noon. The variability occurring in this tropical cyclone phase is similar to the daily variations observed in Cempaka. This condition changes when Dahlia storms weaken into a tropical depression, the peak of rain intensity re-occur in the morning until noon, just like the early tropical depressive phase before the tropical cyclone phase.

From the description of the rainfall charts presented in the above paragraph, it can be seen that in the case of Cempaka and Dahlia storms there is a similar pattern of daily rainfall during tropical storms reaching the peak phase of each storm, ie high rainfall intensity at night until early day, and weaker rain intensity in the morning until noon. This is possible because of the slow convection process due to cloud cover around the storm.

The variability in both storms, especially the Cempaka storm, also affects rainfall patterns on the affected land. From the rainfall charts in Yogyakarta Geophysical Station as showed in 
Fig 5 , it can be observed that the daily rain pattern in Yogyakarta Geophysical Station becomes high during the day and night, and weakens in the early hours and evenings. This happens when Cempaka is active. While on another day of the same month, the daily rainfall pattern of Yogyakarta Geophysical Station is higher rainfall during the day until night and lower in the early hours until the morning, such as the pattern of mainland rainfall in general due to the convective process.

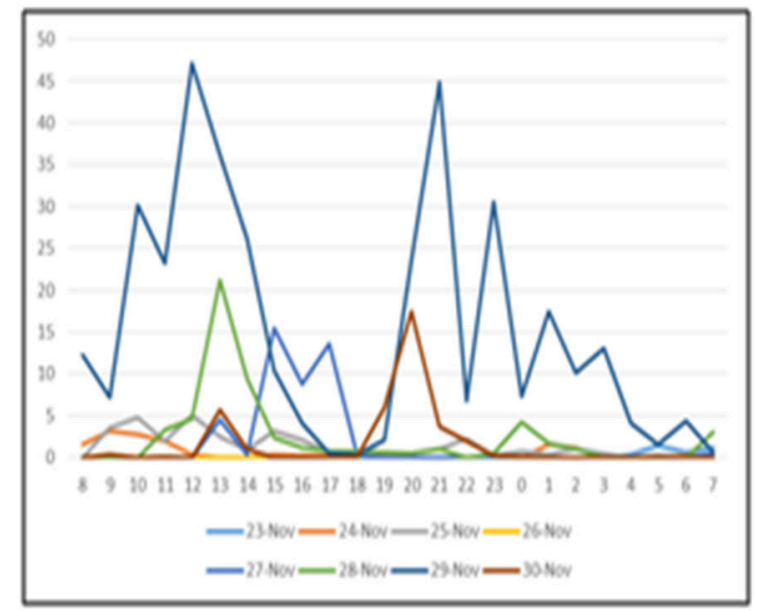

Figure 5. Rainfall intensity per hour in Geophysical Station of Yogyakarta. The X-axis shows local time.

\section{Conclusion}

The diurnal rainfall was clearly observed at the peak phase of TC Cempaka and TC Dahlia that formed in the southern seas of Indonesia, the rainfall graphs show the rainfall peak at night and early morning and weakening in the daylight until afternoon. While on land, the peak of rain occurs during the daylight and night, and weakens in the afternoon and early morning.

\section{References}

[1] Bowman, K. P., J. C. Collier, G. R. North, Q. Wu, E. Ha,. and J. Hardin.(2005). Diurnal cycle of tropical precipitation in Tropical Rainfall Measuring Mission (TRMM) satellite and ocean buoy rain gauge data, J. Geophys. Res., 110, D21104, doi:10.1029/2005JD005763.

[2] Bowman, K. Pand M. D. Fowler. (2015). The diurnal cycle of precipitation in tropical cyclones. J. Climate, 28, 5325-5334, doi:https://doi.org/10.1175/JCLI-D-1400804.1.
[3] Cecil, D. Jand M. Wingo. (2009). Comparison of TRMM rain-rate retrievals in tropical cyclones. J. Meteor. Soc. Japan, 87A, 369-380, doi:https://doi.org/10.2151/jmsj.87A.369.

[4] Gray, W. M., and R. W. Jacobson Jr. (1977). Diurnal variation of deep cumulus convection. Mon. Wea. Rev., 105, 11711188, doi:https://doi.org/10.1175/15200493(1977)105<1171:DVODCC>2.0.CO;2

[5] Leppert, D. K., and Cecil, D. J .(2016). Tropical Cyclone Diurnal Cycle as Observed by TRMM, Monthly Weather Rev.,144, doi: 10.1175/MWR-D-15-0358.1

[6] Simpson, J., Adler, R. F., and North, G. R. (1988). A Proposed Tropical Rainfall Measuring Mission (TRMM) Satellite.Bulletin American Met. Soc., Vol 69.

[7] Wu, Q., Z. Ruan, D. Chen, and T. Lian. (2015). Diurnal variations of tropicalcyclone precipitation in the inner andouter rainbands, J. Geophys. Res. Atmos., 120,1-11, doi:10.1002/2014JD022190 